\title{
Intermetallic Reactions in Sn-0.4Co-0.7Cu Solder BGA Packages with an ENIG Surface Finish
}

\author{
T.H. CHUANG, ${ }^{1,2}$ C.C. JAIN, ${ }^{1}$ and H.M. WU ${ }^{1}$ \\ 1.-Institute of Materials Science and Engineering, National Taiwan University, Taipei 106, \\ Taiwan. 2.-e-mail: tunghan@ntu.edu.tw
}

\begin{abstract}
As-cast $\mathrm{Sn}-0.4 \mathrm{Co}-0.7 \mathrm{Cu}$ solder contains both $\left(\mathrm{Cu}_{0.98} \mathrm{Co}_{0.02}\right)_{6} \mathrm{Sn}_{5}$ and $\left(\mathrm{Co}_{0.85} \mathrm{Cu}_{0.15}\right)$ $\mathrm{Sn}_{3}$ intermetallic phases in the matrix. After reflowing, the Au thin film in the electroless Ni/immersion $\mathrm{Au}$ (ENIG) surface-finished $\mathrm{Sn}-0.4 \mathrm{Co}-0.7 \mathrm{Cu}$ solder ball grid array (BGA) packages dissolved rapidly into the solder matrix to form $\mathrm{AuSn}_{4}$ intermetallics, and a thin layer of $\left(\mathrm{Cu}_{0.57} \mathrm{Ni}_{0.35} \mathrm{Au}_{0.08}\right)_{6} \mathrm{Sn}_{5}$ intermetallic compound appeared at the solder/pad interface, growing very slowly during aging at $100^{\circ} \mathrm{C}$. Increasing the aging temperature to $150^{\circ} \mathrm{C}$ caused the formation of a new intermetallic layer, $\left(\mathrm{Ni}_{0.79} \mathrm{Cu}_{0.21}\right)_{3} \mathrm{Sn}_{4}$, at the $\left(\mathrm{Cu}_{0.57-}\right.$ $\left.\mathrm{Ni}_{0.35} \mathrm{Au}_{0.08}\right)_{6} \mathrm{Sn}_{5} / \mathrm{Ni}$ interface. The reflowed $\mathrm{Sn}-0.4 \mathrm{Co}-0.7 \mathrm{Cu}$ BGA packages have a ball shear strength of $6.8 \mathrm{~N}$, which decreases to about $5.7 \mathrm{~N}$ and $5.5 \mathrm{~N}$ after aging at $100^{\circ} \mathrm{C}$ and $150^{\circ} \mathrm{C}$, respectively. The reflowed and aged solder joints fractured across the solder balls with ductile characteristics in ball shear tests.
\end{abstract}

Key words: $\mathrm{Sn}-0.4 \mathrm{Co}-0.7 \mathrm{Cu}, \mathrm{Au} / \mathrm{Ni} / \mathrm{Cu}$ pads, intermetallic compounds, ball shear strength

\section{INTRODUCTION}

For the development of $\mathrm{Pb}$-free solders, the eutectic $\mathrm{Sn}-\mathrm{Ag}-\mathrm{Cu}$ alloy has drawn special attention due to its merits of superior strength, ductility, and resistance to creep and fatigue. ${ }^{1}$ However, alloying with $\mathrm{Ag}$ in this ternary eutectic solder increases its material cost. In addition, the element $\mathrm{Ag}$ has biologically toxic effects on the environment. Liu et al. suggested that the eutectic $\mathrm{Sn}-\mathrm{Co}-\mathrm{Cu}$ alloy could be an alternative to the $\mathrm{Sn}-\mathrm{Ag}-\mathrm{Cu}$ eutectic solder. ${ }^{2}$ The use of Co as a substitute for Ag in ternary eutectic $\mathrm{Sn}-\mathrm{Ag}-\mathrm{Cu}$ solder leads to a great reduction of materials cost. Liu et al. proposed a ternary $\mathrm{Sn}-\mathrm{Co}-\mathrm{Cu}$ phase diagram by using the calculation of phase diagram (CALPHAD) methodology. ${ }^{3}$ The eutectic temperature thus calculated lies at $224^{\circ} \mathrm{C}$, and the alloy composition of this eutectic phase is Sn-0.4 $\mathrm{Co}-0.7 \mathrm{Cu}$. Andersson et al. further investigated the microstructure and mechanical properties of such a

(Received February 24, 2008; accepted May 23, 2008; published online August 21, 2008) eutectic Sn-0.4Co-0.7Cu alloy. ${ }^{4}$ They found that both $(\mathrm{Co}, \mathrm{Cu}) \mathrm{Sn}_{2}$ and $(\mathrm{Cu}, \mathrm{Co})_{6} \mathrm{Sn}_{5}$ intermetallic compounds formed in this alloy. The ultimate tensile stress (UTS) of $\mathrm{Sn}-0.4 \mathrm{Co}-0.7 \mathrm{Cu}$ as measured under various strain rates of $10^{-3} \mathrm{~s}^{-1}, 10^{-4} \mathrm{~s}^{-1}$, and $10^{-5} \mathrm{~s}^{-1}$ are $30.4 \mathrm{MPa}, 23.4 \mathrm{MPa}$, and $17.3 \mathrm{MPa}$, respectively, which are lower than those of $\mathrm{Sn}-4.0 \mathrm{Ag}-0.5 \mathrm{Cu}$ and $\mathrm{Sn}-37 \mathrm{~Pb}$. The interfacial reactions between $\mathrm{Sn}-0.4 \mathrm{Co}-0.7 \mathrm{Cu}$ eutectic alloy and immersion $\mathrm{Au} /$ electroless $\mathrm{Ni}(\mathrm{P}) / \mathrm{Cu}$ substrates have also been analyzed by Sun et al. ${ }^{5}$ Both $\mathrm{CoSn}_{2}$ and $\mathrm{Cu}_{6} \mathrm{Sn}_{5}$ particles were found in the $\mathrm{Sn}-0.4 \mathrm{Co}-0.7 \mathrm{Cu}$ solder matrix, while only one ternary $(\mathrm{Cu}, \mathrm{Ni})_{6} \mathrm{Sn}_{5}$ intermetallic compound appeared at the solder/pad interface. The $\mathrm{Ni}_{3} \mathrm{Sn}_{4}$ intermetallic phase, as commonly reported in the literature ${ }^{6-8}$ for the interfacial reactions between $\mathrm{Sn}$-based solders and $\mathrm{Ni}$ substrates, was absent in the study of Sun et al..$^{5}$ In order to clarify the intermetallic reactions in this ternary eutectic Sn-0.4Co-0.7Cu alloy system, the chemical composition and morphology of intermetallic compounds formed in the Sn-0.4Co-0.7 $\mathrm{Cu}$ solder matrix and at its joint interface with 
$\mathrm{Au} / \mathrm{Ni} / \mathrm{Cu}$ pads after reflowing and aging processes were analyzed. In addition, the growth of interfacial intermetallics was measured and its kinetics discussed. Finally, the effects of various intermetallic compounds in the solder matrix on the ball shear strength of solder joints were evaluated. Under the consideration of industrial application, all studies were conducted in real $\mathrm{Sn}-0.4 \mathrm{Co}-0.7 \mathrm{Cu}$ solder ball grid array (BGA) packages with a commercialized ENIG surface finish.

\section{EXPERIMENTAL}

For the preparation of eutectic $\mathrm{Sn}-0.4 \mathrm{Co}-0.7 \mathrm{Cu}$ solder in this study, a Sn-Co master alloy was melted in a vacuum induction furnace, and then adequate amounts of $\mathrm{Sn}$ and $\mathrm{Cu}$ elements were added. The eutectic point of this solder was measured via a differential scanning calorimeter (DSC) with a heating rate of $10^{\circ} \mathrm{C} / \mathrm{min}$. The geometry of the ball grid array (BGA) packages, as shown in a prior work, contains a Si dummy die attached to a bismaleimide triazine (BT) resin substrate and encapsulated with molding compound. ${ }^{9}$ Each package was fitted with $49 \mathrm{Cu}$ pads electroless-plated with $5-\mu \mathrm{m}$-thick $\mathrm{Ni}$ and immersion plated with $0.5-\mu \mathrm{m}$-thick $\mathrm{Au}$ according to the industrial ENIG process. ${ }^{10}$ The 0.4 -mm-diameter $\mathrm{Sn}-0.4 \mathrm{Co}-0.7 \mathrm{Cu}$ solder balls were dipped in rosin mildly activated (RMA) flux and then placed on the $\mathrm{Au} / \mathrm{Ni} / \mathrm{Cu}$ pads. The specimens were reflowed in a hot-air furnace using a soaking temperature of $190^{\circ} \mathrm{C}$ and a peak temperature of $240^{\circ} \mathrm{C}$. Such a temperature profile for the reflowing process is similar to that used in our prior studies on $\mathrm{Sn}-3 \mathrm{Ag}-0.5 \mathrm{Cu}$ solder BGA packages. ${ }^{11,12}$ After reflowing, certain specimens were further aged at $100^{\circ} \mathrm{C}$ and $150^{\circ} \mathrm{C}$ for various time periods ranging from $100 \mathrm{~h}$ to $1000 \mathrm{~h}$.

The reflowed and aged BGA packages were cross sectioned through a row of solder balls, ground with 2000 grid $\mathrm{SiC}$ paper, and then polished with $0.3 \mu \mathrm{m}$ $\mathrm{Al}_{2} \mathrm{O}_{3}$ powder. The intermetallic compounds were observed by using scanning electron microscopy (SEM). The chemical compositions of various intermetallics formed in $\mathrm{Sn}-0.4 \mathrm{Co}-0.7 \mathrm{Cu}$ alloy and solder joints were analyzed with an electron probe microanalyzer (EPMA) and are listed in Table I. The growth thickness of intermetallic compounds $\left(X_{\text {IMC }}\right)$ and the consumption of the $\mathrm{Ni}$ layer $\left(\Delta X_{\mathrm{Ni}}\right)$ were measured for each soldering condition (per reaction temperature and time).

The bonding strengths of the solder joints in the BGA packages were measured by using ball shear tests. The measurements were conducted at a shear rate of $0.1 \mathrm{~mm} / \mathrm{s}$ and a shear height of $80 \mu \mathrm{m}$ (about one-quarter of the reflowed ball height). The fractography of the solder joints after ball shear tests was observed by using scanning electron microscopy (SEM).

\section{RESULTS AND DISCUSSION}

The DSC curve in Fig. 1 reveals that the Sn-0.4Co- $0.7 \mathrm{Cu}$ solder in this study possesses a eutectic point at $229^{\circ} \mathrm{C}$, which is about $5^{\circ} \mathrm{C}$ higher than that calculated by Liu et al. ${ }^{3}$ Two types of intermetallic phases were identified by Andersson et al. using energy-dispersive x-ray spectrometry (EDX). ${ }^{4}$ The first intermetallic had a chemical composition (at.\%) of $\mathrm{Sn}: \mathrm{Co}: \mathrm{Cu}=59.5: 6: 34.5$, which corresponded to the $(\mathrm{Cu}, \mathrm{Co})_{6} \mathrm{Sn}_{5}$ phase. The chemical composition of the second intermetallic compounds, as analyzed by Andersson et al., was $\mathrm{Sn}: \mathrm{Co}: \mathrm{Cu}=70: 4: 26$, which suggested the $(\mathrm{Co}, \mathrm{Cu})$ $\mathrm{Sn}_{2}$ phase. Andersson et al. also reported that it was difficult to distinguish the shape difference between

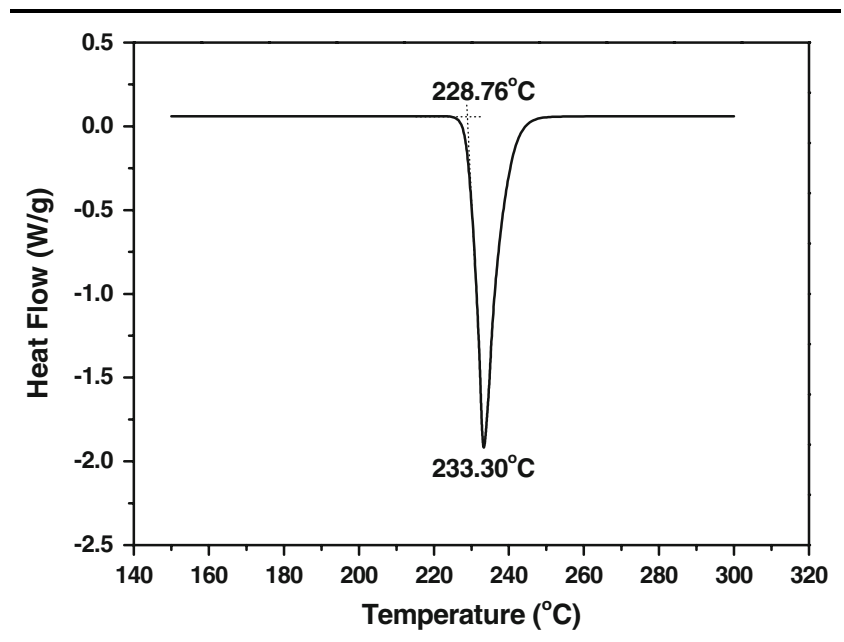

Fig. 1. DSC analysis of the eutectic Sn-0.4Co-0.7Cu solder.

Table I. Chemical Compositions (at.\%) of the Intermetallic Compounds Formed in the ENIG-SurfaceFinished Sn-0.4Co-0.7Cu Solder BGA Packages after Reflowing and Aging Processes

\begin{tabular}{|c|c|c|c|c|c|c|}
\hline & Sn & Co & $\mathbf{C u}$ & Au & $\mathbf{N i}$ & Intermetallic Phases \\
\hline IMC1 & 46.34 & 1.28 & 52.38 & - & - & $\left(\mathrm{Cu}_{0.98} \mathrm{Co}_{0.02}\right)_{6} \mathrm{Sn}_{5}$ \\
\hline IMC2 & 75.47 & 20.81 & 3.72 & - & - & $\left(\mathrm{Co}_{0.85} \mathrm{Cu}_{0.15}\right) \mathrm{Sn}_{3}$ \\
\hline IMC3 & 79.86 & - & - & 20.14 & - & $\mathrm{AuSn}_{4}$ \\
\hline IMC4 & 45.87 & - & 31.03 & 4.05 & 19.05 & $\left(\mathrm{Cu}_{0.57} \mathrm{Ni}_{0.35} \mathrm{Au}_{0.08}\right)_{6} \mathrm{Sn}_{5}$ \\
\hline IMC5 & 55.38 & - & 9.45 & - & 35.17 & $\left(\mathrm{Ni}_{0.79} \mathrm{Cu}_{0.21}\right)_{3} \mathrm{Sn}_{4}$ \\
\hline IMC6 & 78.63 & - & - & 14.16 & 7.21 & $\left(\mathrm{Au}_{0.66} \mathrm{Ni}_{0.34}\right) \mathrm{Sn}_{4}$ \\
\hline
\end{tabular}



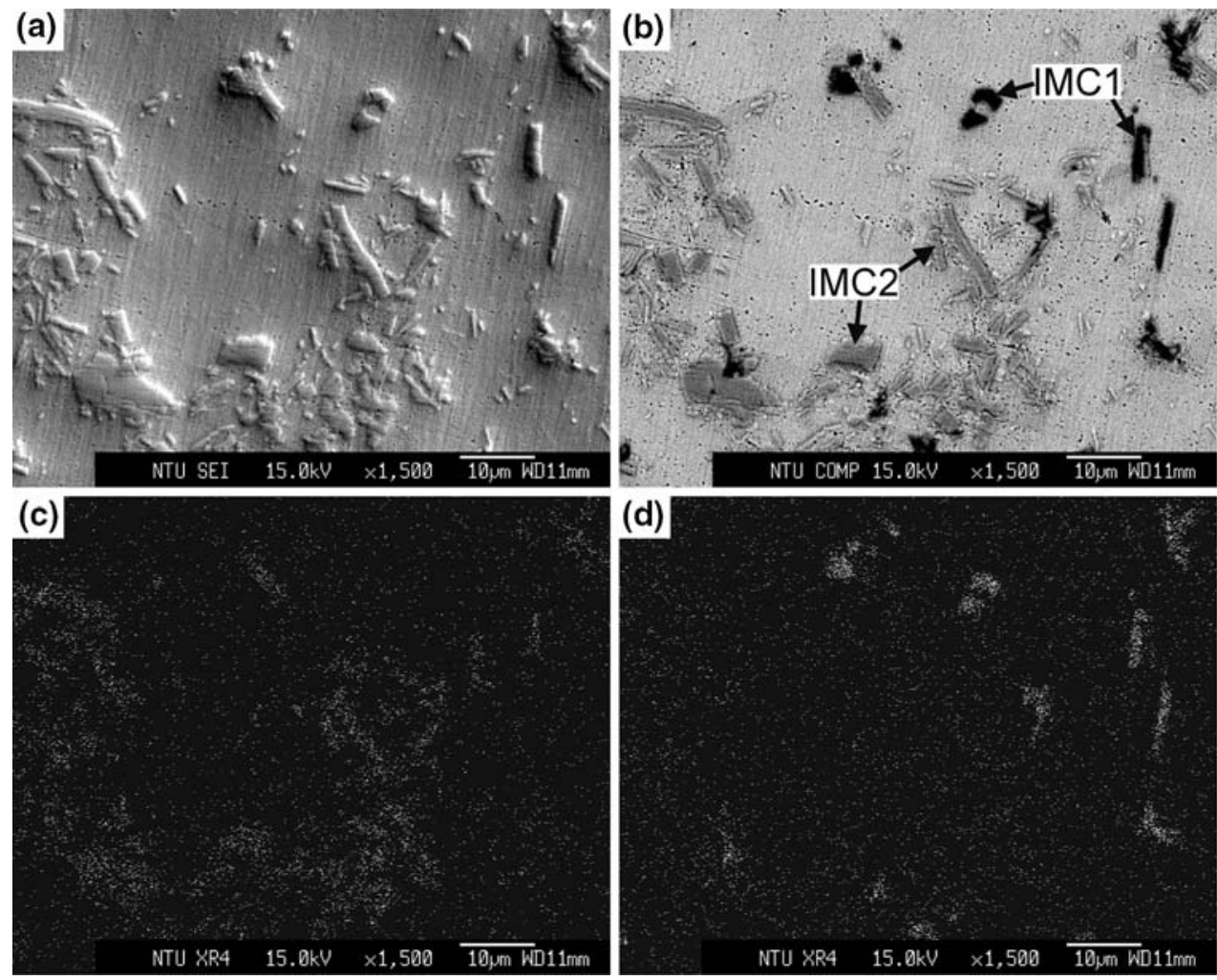

Fig. 2. Microstructure and element mapping of as cast Sn-0.4Co-0.7Cu solder: (a) SEI, (b) BSE, (c) Co, and (d) Cu.

$(\mathrm{Cu}, \mathrm{Co})_{6} \mathrm{Sn}_{5}$ and $(\mathrm{Co}, \mathrm{Cu}) \mathrm{Sn}_{2}$ phases. ${ }^{4}$ According to our analyses using an electron probe microanalyzer (EPMA), the various types of intermetallic phases cannot be identified via secondary electron imaging (SEI), as shown in Fig. 2a. However, in Fig. 2b, for which a back-scattering electron image (BSE) was used, two different intermetallics are clearly observed. EPMA mapping for elements indicates that the gray phase is Co-rich (Fig. 2c) and that the black phase is $\mathrm{Cu}$-rich (Fig. 2d). Further quantitative analyses reveal that the chemical composition (at.\%) of Cu-rich intermetallics in $\mathrm{Sn}-0.4 \mathrm{Co}-0.7 \mathrm{Cu}$ alloy is $\mathrm{Sn}: \mathrm{Co}: \mathrm{Cu}=46.34: 1.28: 52.39$, which corresponds to the $\left(\mathrm{Cu}_{0.98} \mathrm{Co}_{0.02}\right)_{6} \mathrm{Sn}_{5}$ phase (IMC1). EPMA analyses also give the chemical composition (at.\%) of Co-rich intermetallics as $\mathrm{Sn}: \mathrm{Co}: \mathrm{Cu}=$ 75.47:20.80:3.73, which is near a $\left(\mathrm{Co}_{0.85} \mathrm{Cu}_{0.15}\right) \mathrm{Sn}_{3}$ phase (IMC2). The existence of such $\left(\mathrm{Co}_{0.85} \mathrm{Cu}_{0.15}\right)$ $\mathrm{Sn}_{3}$ intermetallics is inconsistent with the $\mathrm{CoSn}_{2}$ phase in the ternary phase diagram calculated by Liu et al., ${ }^{3}$ which is based on the experimental data for a Sn-Co binary system reported by Ishida and Nishizawa ${ }^{13}$ and Okamoto. ${ }^{14}$ In fact, the stoichiometric ratio of $\mathrm{Sn} /(\mathrm{Co}+\mathrm{Cu})$ for the chemical composition of the Co-rich phase as analyzed by using EDX by Andersson et al. ${ }^{4}$ is 2.33, which is also quite far from that for $\mathrm{CoSn}_{2}$. The results imply that an extra peritectic reaction, $\mathrm{L}+\mathrm{CoSn}_{2} \rightarrow$ $\mathrm{CoSn}_{3}$, might exist between $229^{\circ} \mathrm{C}$ and $525^{\circ} \mathrm{C}$ in the binary Co-Sn phase diagram reported by Ishida and Nishizawa $^{13}$ and Okamoto. ${ }^{14}$
After reflowing, the Au thin film dissolved rapidly to form many $\mathrm{AuSn}_{4}$ intermetallic compounds (IMC3) in the solder matrix, as shown in Fig. 3. Certain $\mathrm{AuSn}_{4}$ intermetallics were also found to have attached to the surface of the $\left(\mathrm{Co}_{0.85} \mathrm{Cu}_{0.15}\right) \mathrm{Sn}_{3}$ phase (IMC2). Figure 3 reveals that, accompanying the formation of $\mathrm{AuSn}_{4}$ intermetallic compounds in the solder matrix, a $\left(\mathrm{Cu}_{0.57} \mathrm{Ni}_{0.35} \mathrm{Au}_{0.08}\right)_{6} \mathrm{Sn}_{5}$ intermetallic layer (IMC4) appears at the interface between the $\mathrm{Sn}-0.4 \mathrm{Co}-0.7 \mathrm{Cu}$ solder ball and $\mathrm{Ni}$ layer on the $\mathrm{Cu}$ pad. In contrast, the amount of $\left(\mathrm{Cu}_{0.98}\right.$ $\left.\mathrm{Co}_{0.02}\right)_{6} \mathrm{Sn}_{5}$ intermetallic phase (IMC1) in the as-cast $\mathrm{Sn}-0.4 \mathrm{Co}-0.7 \mathrm{Cu}$ solder matrix decreased significantly. The $\mathrm{Cu}$ atoms in the $\left(\mathrm{Cu}_{0.98} \mathrm{Co}_{0.02}\right)_{6} \mathrm{Sn}_{5}$ intermetallics have migrated from the solder matrix to the $\mathrm{Sn}-0.4 \mathrm{Co}-0.7 \mathrm{Cu} / \mathrm{Ni}$ interface to form the $\left(\mathrm{Cu}_{0.57} \mathrm{Ni}_{0.35} \mathrm{Au}_{0.08}\right)_{6} \mathrm{Sn}_{5}$ intermetallic (IMC4) during the reflowing process.

Aging at $100^{\circ} \mathrm{C}$ for $100 \mathrm{~h}$ to $1000 \mathrm{~h}$ caused the interfacial intermetallic layer (IMC4) to grow very slowly, as shown in Fig. 4. In addition, the chemical compositions of the IMC4 intermetallic compound at the $\mathrm{Sn}-0.4 \mathrm{Co}-0.7 \mathrm{Cu} / \mathrm{Ni}$ interfaces remained almost unchanged. On the other hand, many $\mathrm{AuSn}_{4}$ intermetallics (IMC3) combined with the $\left(\mathrm{Co}_{0.85} \mathrm{Cu}_{0.15}\right)$ $\mathrm{Sn}_{3}$ intermetallic phase (IMC2) in the solder matrix. Figure 5 reveals that the slender $\mathrm{AuSn}_{4}$ intermetallics were distributed uniformly in the interior of the solder balls. Figure 6 shows that, as the aging temperature was raised to $150^{\circ} \mathrm{C}$, the thickness of the interfacial intermetallic layers increased 

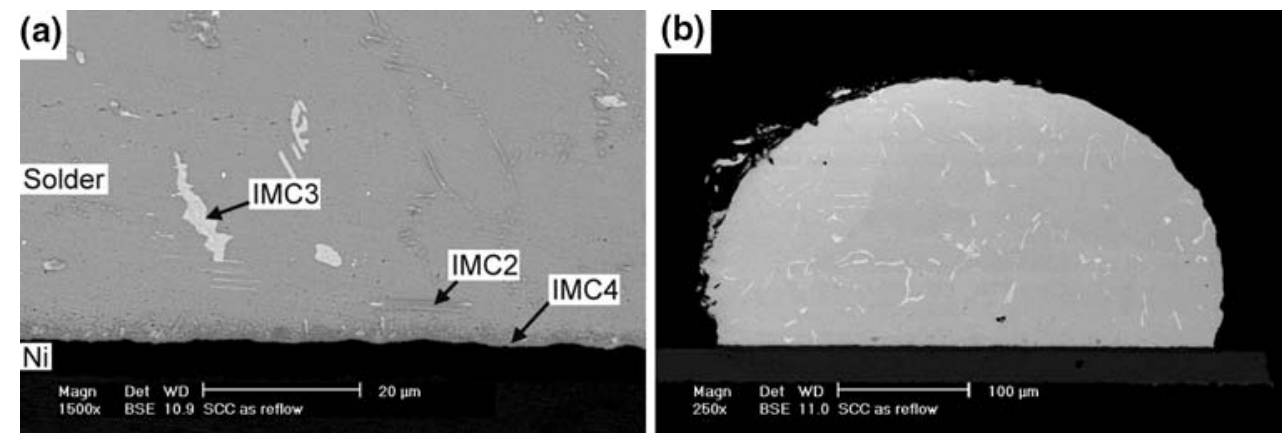

Fig. 3. Microstructure of the solder joint in a reflowed Sn-0.4Co-0.7Cu BGA package with Au/Ni/Cu pad.
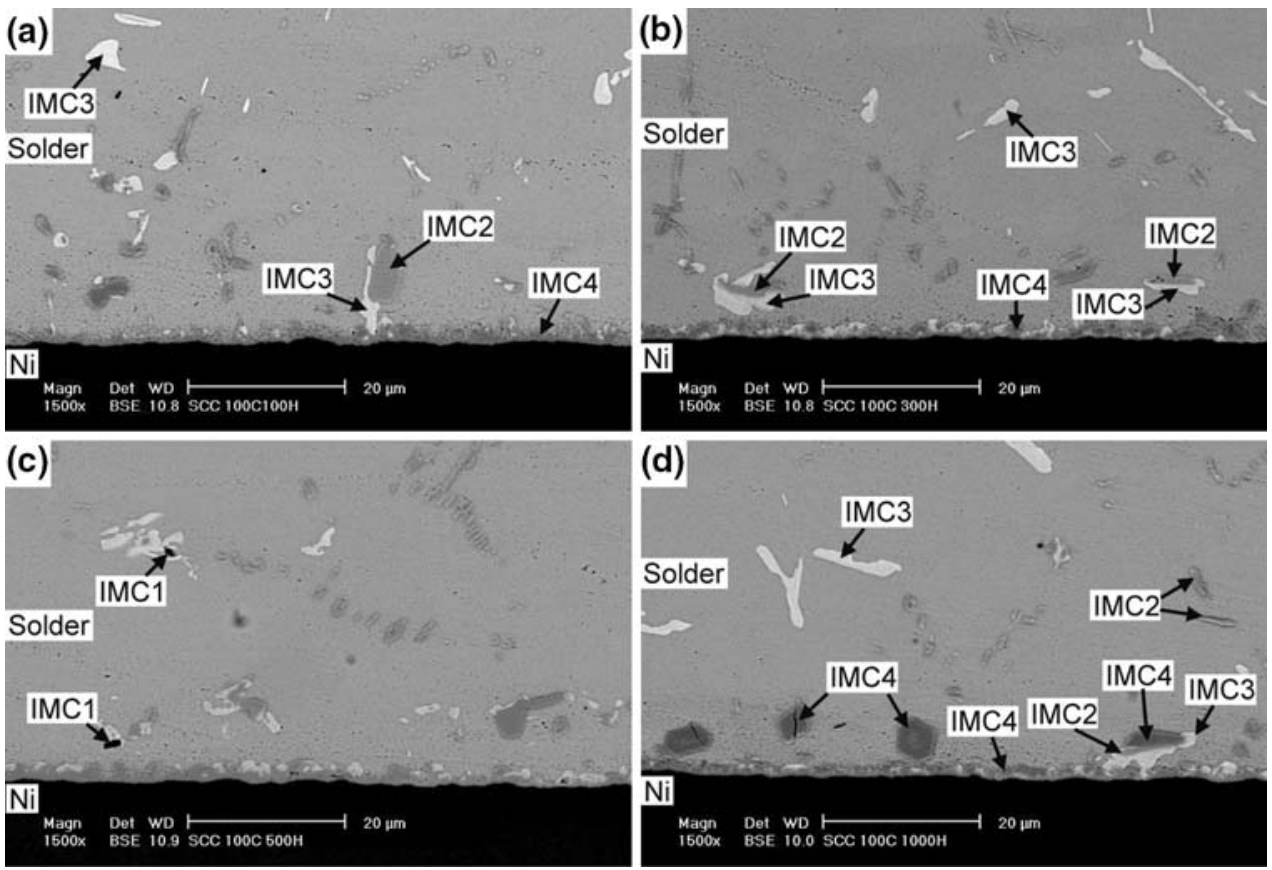

Fig. 4. Morphology of the intermetallic compounds formed in the Sn-0.4Co-0.7Cu solder BGA packages with ENIG surface finish after aging at $100^{\circ} \mathrm{C}$ for various time periods: (a) $100 \mathrm{~h}$, (b) $300 \mathrm{~h}$, (c) $500 \mathrm{~h}$, and (d) $1000 \mathrm{~h}$.

observably with the aging time. EPMA analyses indicated that a new IMC5 intermetallic layer with a composition of $\left(\mathrm{Ni}_{0.79} \mathrm{Cu}_{0.21}\right)_{3} \mathrm{Sn}_{4}$ formed below the IMC4 intermetallic layer. The $\left(\mathrm{Ni}_{0.79} \mathrm{Cu}_{0.21}\right)_{3} \mathrm{Sn}_{4}$ intermetallic layer (IMC5) also grew with aging time at $150^{\circ} \mathrm{C}$. This result is attributed to the interfacial reaction of IMC4 intermetallics with the $\mathrm{Ni}$ layer on the $\mathrm{Cu}$ pads due to an increase of $\mathrm{Ni}$ diffusion at $150^{\circ} \mathrm{C}$. In addition, it can be found that the slender $\mathrm{AuSn}_{4}$ intermetallic compounds (IMC3) in the solder matrix have coarsened to a cluster shape, and that their composition has changed to $\left(\mathrm{Au}_{0.66} \mathrm{Ni}_{0.34}\right) \mathrm{Sn}_{4}$, marked as IMC6 in Fig. 6. This result indicates that the $\mathrm{Ni}$ atoms in the ENIG surface finish have also diffused through the interfacial intermetallic layers (IMC5/IMC4) and $\mathrm{Sn}-0.4 \mathrm{Co}-0.7 \mathrm{Cu}$ solder matrix and dissolved into the $\mathrm{AuSn}_{4}$ intermetallic phase (IMC3). The coarsening of $\mathrm{AuSn}_{4}$ intermetallic compounds during aging at $150^{\circ} \mathrm{C}$ can be confirmed in Fig. 7. In addition, Fig. 7 also reveals that significantly thicker intermetallic layers appear and grow at the interface between the $\mathrm{Sn}-0.4 \mathrm{Co}-0.7 \mathrm{Cu}$ solder balls and the $\mathrm{Ni} / \mathrm{Cu}$ pads. In comparison to those in Figs. 6 and 7, the solder/pad interfaces in Figs. 4 and 5 have only tiny amounts of intermetallic compounds.

The thickness of the $\left(\mathrm{Cu}_{0.57} \mathrm{Ni}_{0.35} \mathrm{Au}_{0.08}\right)_{6} \mathrm{Sn}_{5}$ and $\left(\mathrm{Ni}_{0.79} \mathrm{Cu}_{0.21}\right)_{3} \mathrm{Sn}_{4}$ intermetallic layers (IMC4 and IMC5) formed at the interface between the Sn-0.4Co- $0.7 \mathrm{Cu}$ solder balls and the $\mathrm{Ni} / \mathrm{Cu}$ pads during aging at $100^{\circ} \mathrm{C}$ and $150^{\circ} \mathrm{C}$ were measured and are shown in Fig. 8a. In order to clarify the growth mechanism of intermetallic compounds, logarithmic plots of the intermetallic thickness $\left(X_{\text {IMC }}\right)$ as a function of aging time are given in Fig. 8b. The slopes $(n)$ calculated from the curves in 

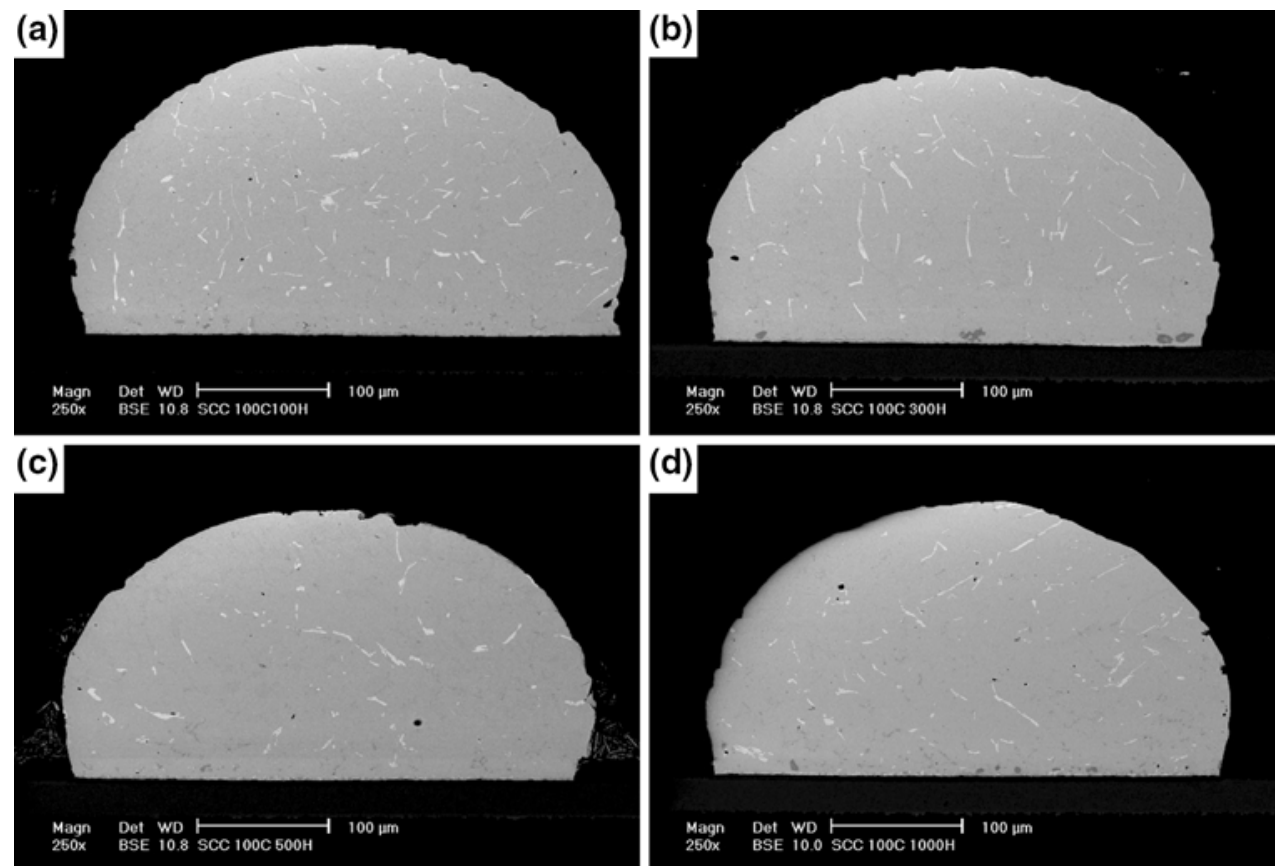

Fig. 5. Cross section of solder balls in Sn-0.4Co-0.7Cu BGA packages with ENIG surface finish after aging at $100^{\circ} \mathrm{C}$ for various times: (a) $100 \mathrm{~h}$, (b) $300 \mathrm{~h}$, (c) $500 \mathrm{~h}$, and (d) $1000 \mathrm{~h}$.
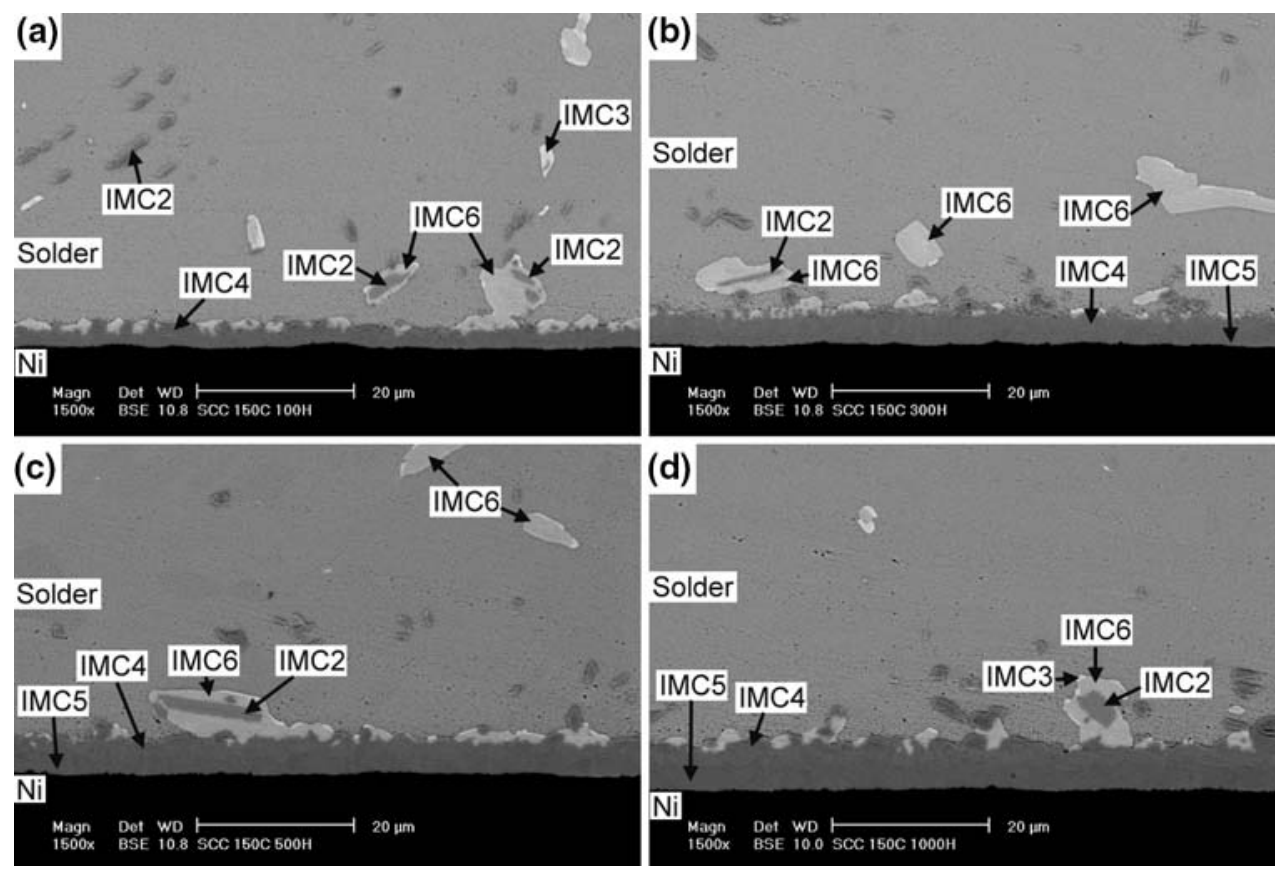

Fig. 6. Morphology of the intermetallic compounds formed in the Sn-0.4Co-0.7Cu solder BGA packages with ENIG surface finish after aging at $150^{\circ} \mathrm{C}$ for various time periods: (a) $100 \mathrm{~h}$, (b) $300 \mathrm{~h}$, (c) $500 \mathrm{~h}$, and (d) $1000 \mathrm{~h}$.

Fig. $8 \mathrm{~b}$ are 0.25 for IMC4 formed at both $100^{\circ} \mathrm{C}$ and $150^{\circ} \mathrm{C}$, and 0.34 for IMC5 formed at $150^{\circ} \mathrm{C}$. The $n$ values for intermetallic growth during aging in the ENIG-surface-finished $\mathrm{Sn}-0.4 \mathrm{Co}-0.7 \mathrm{Cu}$ solder BGA packages differ from those obtained from a diffusion-controlled interfacial reaction $(n=0.5) .{ }^{15}$
The explanation for this result is that the IMC4 intermetallic layer was produced by the migration of $\mathrm{Cu}$ atoms from the IMC1 in the solder matrix, which subsequently reacted with the $\mathrm{Ni}$ layer on the $\mathrm{Cu}$ pad. The gradual diminishing of the IMC1 intermetallic phase in the solder matrix with aging time 

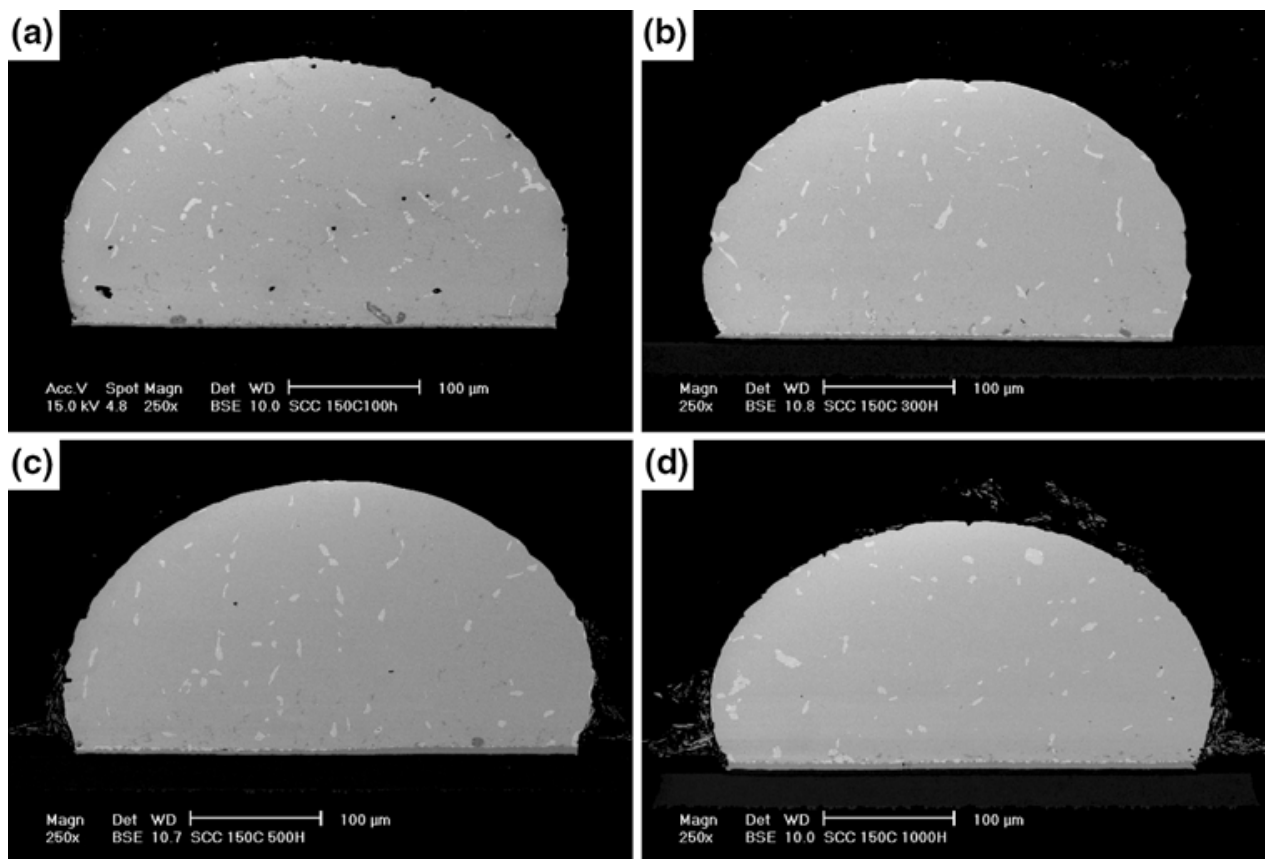

Fig. 7. Cross section of solder balls in $\mathrm{Sn}-0.4 \mathrm{Co}-0.7 \mathrm{Cu}$ solder BGA packages with ENIG surface finish after aging at $150^{\circ} \mathrm{C}$ for various times: (a) $100 \mathrm{~h}$, (b) $300 \mathrm{~h}$, (c) $500 \mathrm{~h}$, and (d) $1000 \mathrm{~h}$.

leads to the reduction of the $\mathrm{Cu}$ source for the interfacial reaction in the formation of IMC4. Consequently, the growth of the IMC5 intermetallic layer, which results from the interfacial reaction between IMC4 and $\mathrm{Ni}$, is also retarded with aging time. This is manifested in $n$ values of less than 0.5 for the growth thickness of both IMC4 and IMC5 at the $\mathrm{Sn}-0.4 \mathrm{Co}-0.7 \mathrm{Cu} / \mathrm{Ni}$ interfaces. However, the plots of $\mathrm{Ni}$ consumption thickness accompanying the interfacial intermetallic growth at $100^{\circ} \mathrm{C}$ and $150^{\circ} \mathrm{C}$ reveal $n$ values of 0.59 and 0.53 , respectively, as shown in Fig. 9. The parabolic relation of kinetics analysis indicates that the consumption of the $\mathrm{Ni}$ layer is diffusion controlled. This result confirms that only some of the outward diffused $\mathrm{Ni}$ atoms respond in the growth of the IMC4 and IMC5 interfacial intermetallic layers. The excess $\mathrm{Ni}$ atoms dissolve into the $\mathrm{AuSn}_{4}$ intermetallic clusters in the solder matrix to form the $\left(\mathrm{Au}_{0.66} \mathrm{Ni}_{0.34}\right) \mathrm{Sn}_{4}$ intermetallic phase (IMC6).

The bonding strength of reflowed solder joints in ENIG-surface-finished Sn-0.4Co-0.7Cu BGA packages is $6.8 \mathrm{~N}$, which is about $30 \%$ lower than that in Sn-3Ag-0.5Cu packages with the same surface finish $(9.8 \mathrm{~N}){ }^{11}$ The much higher strength of Sn-3Ag$0.5 \mathrm{Cu}$ as compared with that of $\mathrm{Sn}-0.4 \mathrm{Co}-0.7 \mathrm{Cu}$ solder joints is attributed to the precipitation hardening effect of fine $\mathrm{Ag}_{3} \mathrm{Sn}$ particles in the Sn-3Ag-0.5Cu alloy ${ }^{16}$ Although Sn-0.4Co-0.7Cu solder joints also possess $\left(\mathrm{Co}_{0.85} \mathrm{Cu}_{0.15}\right) \mathrm{Sn}_{3},\left(\mathrm{Cu}_{0.98} \mathrm{Co}_{0.02}\right)_{6} \mathrm{Sn}_{5}$, and $\mathrm{AuSn}_{4}$ intermetallic phases in the solder matrix, their larger size and lower amount lead to smaller strengthening effects in comparison with the $\mathrm{Ag}_{3} \mathrm{Sn}$ precipitates in the $\mathrm{Sn}-3 \mathrm{Ag}-0.5 \mathrm{Cu}$ packages. After aging at $100^{\circ} \mathrm{C}$ and $150^{\circ} \mathrm{C}$ for various times, the bonding strengths of $\mathrm{Sn}-0.4 \mathrm{Co}-0.7 \mathrm{Cu}$ solder joints decreased to about $5.7 \pm 0.3 \mathrm{~N}$ and $5.5 \pm 0.2 \mathrm{~N}$, respectively, as shown in Fig. 10. In the Sn-3Ag-0.5Cu packages, coarsening of $\mathrm{Ag}_{3} \mathrm{Sn}$ precipitates caused the ball shear strengths to decrease drastically to about $6.5 \mathrm{~N}$ and $6.2 \mathrm{~N}$, respectively, after aging at $100^{\circ} \mathrm{C}$ and $150^{\circ} \mathrm{C}$. These results indicate that the degradation of bonding strength in Sn-3Ag-0.5Cu solder joints is more significant than that in $\mathrm{Sn}-0.4 \mathrm{Co}-0.7 \mathrm{Cu}$.

Fractography of the solder joints in reflowed and aged $\mathrm{Sn}-0.4 \mathrm{Co}-0.7 \mathrm{Cu}$ BGA packages revealed ductile fracture characteristics across the solder balls after ball shear tests, as shown in Figs. 11 and 12. It can be seen that the fractured surfaces can be divided into ball shear regions (left side) and dimple fracture regions (right side). Comparing Figs. 11a and $12 \mathrm{a}$ reveals that the ball shear regions in aged specimens are smaller than those in the reflowed state. This phenomenon might be attributed to the coarsening of intermetallic phases in the solder matrix of aged specimens, which resulted in the earlier formation of nucleation sites for dimple fractures.

\section{CONCLUSIONS}

As-cast $\mathrm{Sn}-0.4 \mathrm{Co}-0.7 \mathrm{Cu}$ solder possesses a eutectic point at $224^{\circ} \mathrm{C}$, and contains $\left(\mathrm{Cu}_{0.98} \mathrm{Co}_{0.02}\right)_{6} \mathrm{Sn}_{5}$ and $\left(\mathrm{Co}_{0.85} \mathrm{Cu}_{0.15}\right) \mathrm{Sn}_{3}$ intermetallic phases. During reflowing of Sn-0.4Co-0.7Cu BGA packages with an ENIG surface finish, the $\mathrm{Au}$ thin film dissolved rapidly into the solder matrix to form $\mathrm{AuSn}_{4}$ 

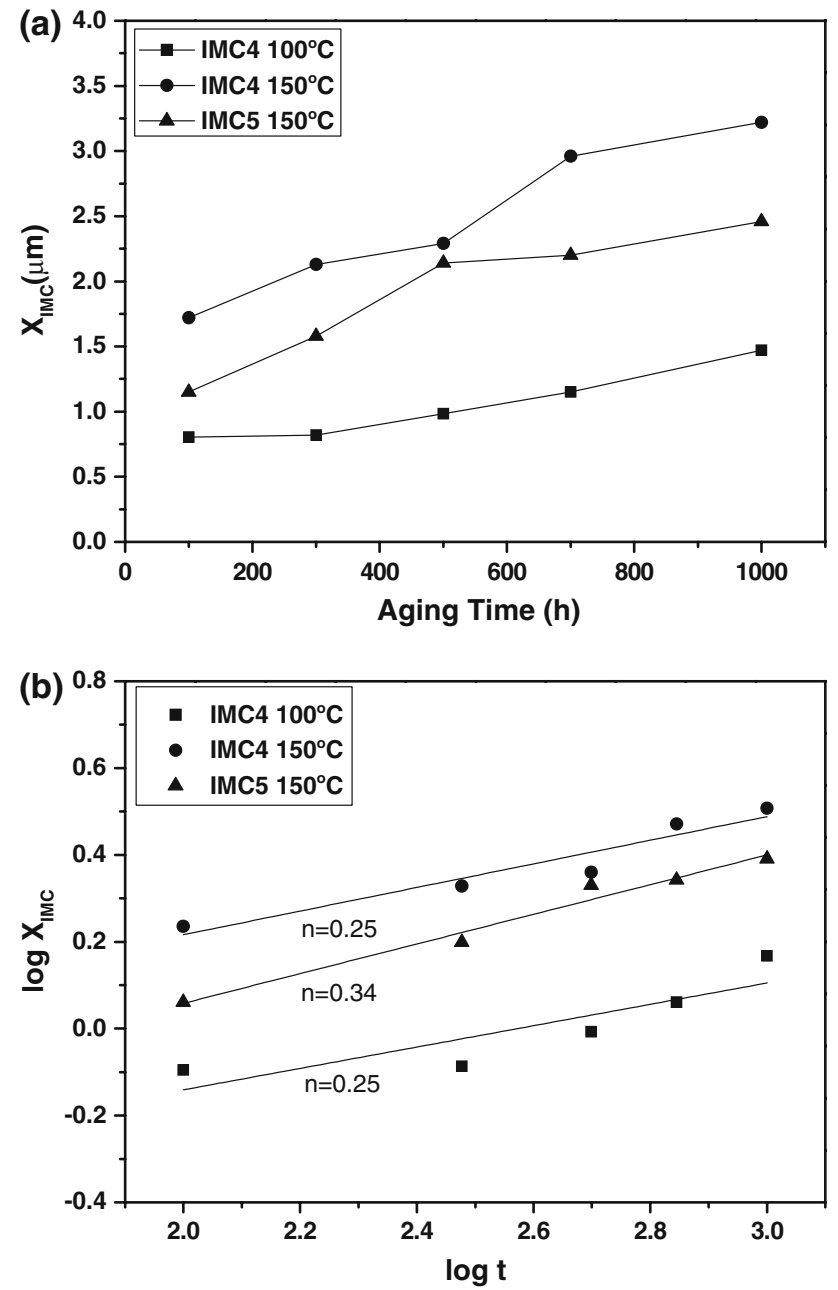

Fig. 8. Growth thickness $\left(X_{\mathrm{IMC}}\right)$ of interfacial intermetallic layers in the $\mathrm{Sn}-0.4 \mathrm{Co}-0.7 \mathrm{Cu}$ solder BGA packages with ENIG surface finish during aging at $100^{\circ} \mathrm{C}$ and $150^{\circ} \mathrm{C}$ for various times (t): (a) $X_{\mathrm{IMC}}$ versus $t$ and (b) $\log X_{\mathrm{IMC}}$ versus $\log t$.

intermetallics. In contrast, the $\mathrm{Cu}$ atoms in $\left(\mathrm{Cu}_{0.98} \mathrm{Co}_{0.02}\right)_{6} \mathrm{Sn}_{5}$ intermetallics migrate to the $\mathrm{Ni}$ layer on the $\mathrm{Cu}$ pad to form a $\left(\mathrm{Cu}_{0.57} \mathrm{Ni}_{0.35}\right.$ $\left.\mathrm{Au}_{0.08}\right)_{6} \mathrm{Sn}_{5}$ intermetallic layer at the $\mathrm{Sn}-0.4 \mathrm{Co}-$ $0.7 \mathrm{Cu} / \mathrm{Ni}$ interface. During further aging at $100^{\circ} \mathrm{C}$, the interfacial intermetallic layer grows very slowly. However, increasing the aging temperature to $150^{\circ} \mathrm{C}$ results in the appearance of an extra layer of $\left(\mathrm{Ni}_{0.79} \mathrm{Cu}_{0.21}\right)_{3} \mathrm{Sn}_{4}$ intermetallics between the $\left(\mathrm{Cu}_{0.57} \mathrm{Ni}_{0.35} \mathrm{Au}_{0.08}\right)_{6} \mathrm{Sn}_{5}$ intermetallics and the $\mathrm{Ni} / \mathrm{Cu}$ pads. Ball shear testing of the reflowed Sn-0.4Co- $0.7 \mathrm{Cu}$ solder joints reveals a bonding strength of $6.8 \mathrm{~N}$, which is about $30 \%$ lower than that of the Sn-3Ag-0.5Cu packages. Aging at $100^{\circ} \mathrm{C}$ and $150^{\circ} \mathrm{C}$ for various times causes the ball shear strength of $\mathrm{Sn}-0.4 \mathrm{Co}-0.7 \mathrm{Cu}$ solder joints to degrade to $5.7 \pm 0.3 \mathrm{~N}$ and $5.5 \pm 0.2 \mathrm{~N}$, respectively. Fractography of the reflowed and aged specimens after ball shear tests shows ductile fracture characteristics across the solder balls.
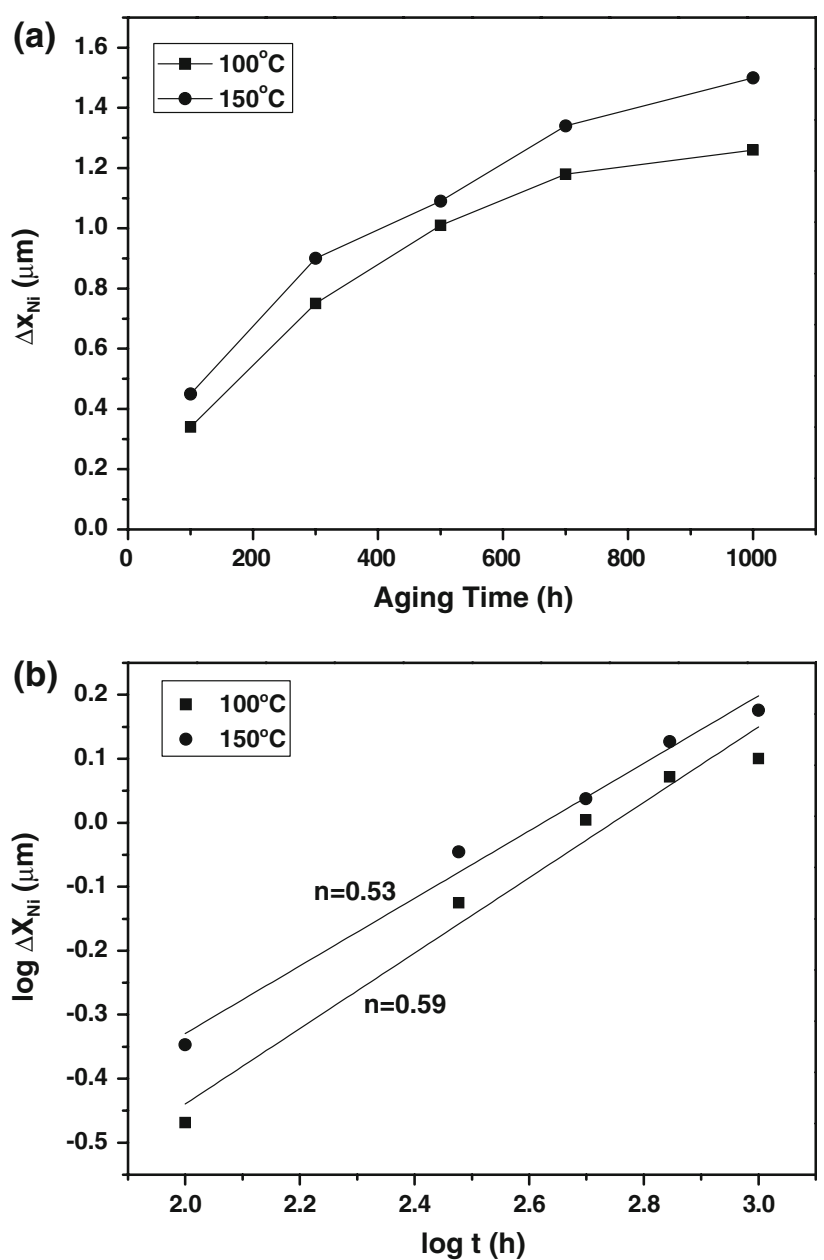

Fig. 9. Consumption thickness $\left(\Delta X_{\mathrm{Ni}}\right)$ of $\mathrm{Ni}$ layers on the Cu pads of Sn-0.4Co-0.7Cu solder BGA packages during aging at $100^{\circ} \mathrm{C}$ and $150^{\circ} \mathrm{C}$ for various times (t): (a) $\Delta X_{\mathrm{Ni}}$ versus $t$ and (b) log $\Delta X_{\mathrm{Ni}}$ versus $\log t$.

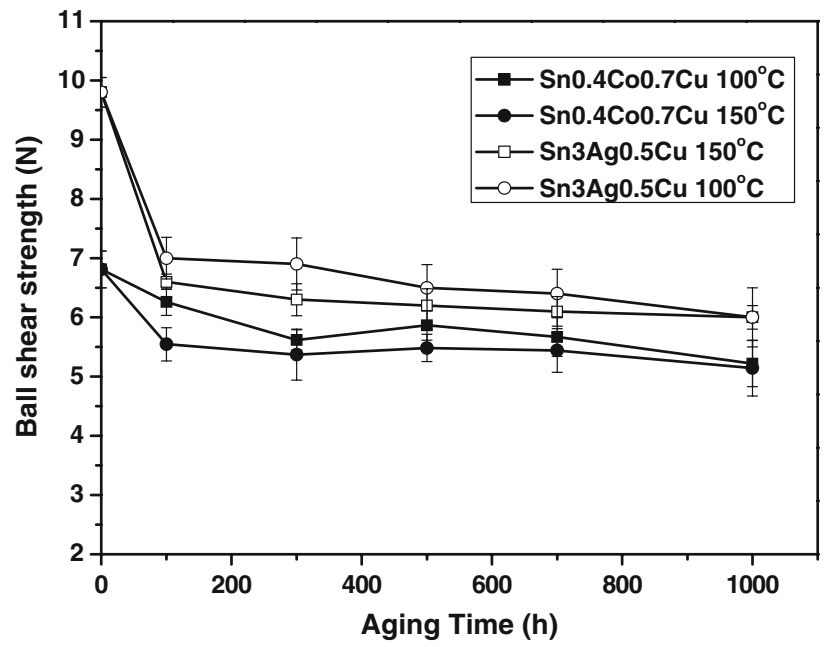

Fig. 10. Ball shear strengths of the solder joints in Sn-0.4Co-0.7Cu and $\mathrm{Sn}-3 \mathrm{Ag}-0.5 \mathrm{Cu}$ solder BGA packages with ENIG surface finish after aging at $100^{\circ} \mathrm{C}$ and $150^{\circ} \mathrm{C}$ for various times. 

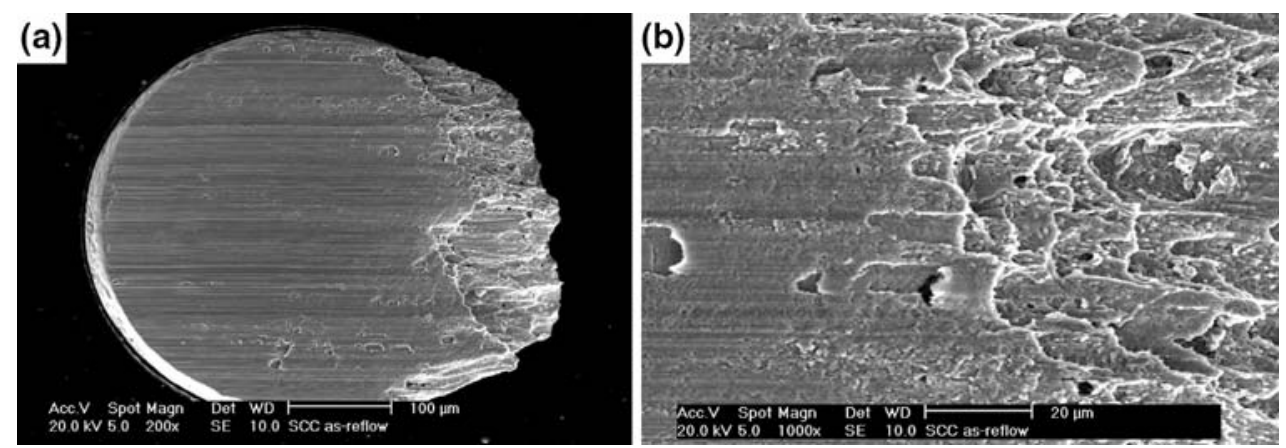

Fig. 11. Typical fractography of the reflowed Sn-0.4Co-0.7Cu solder joints after ball shear testing.
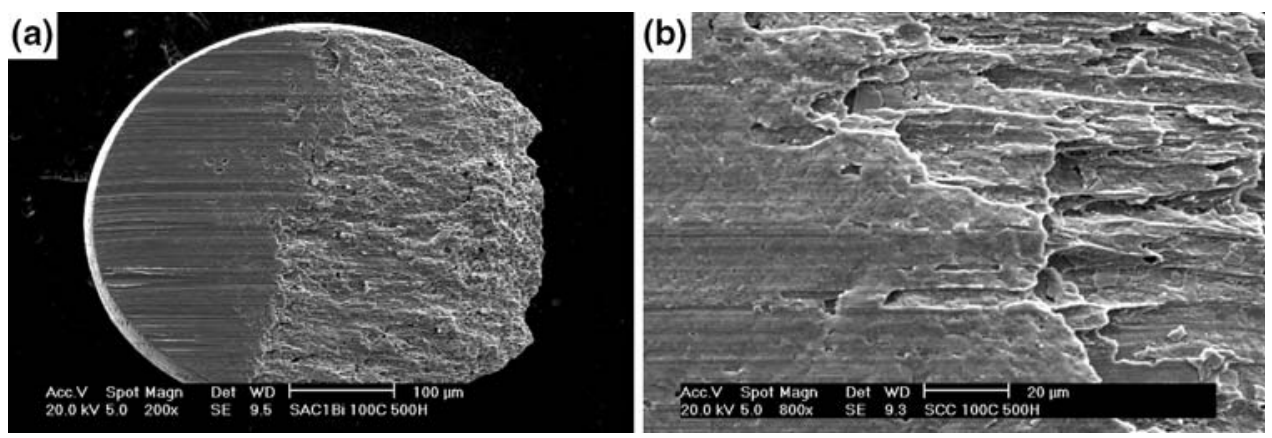

Fig. 12. Typical fractography of the aged Sn-0.4Co-0.7Cu solder joints after ball shear testing.

\section{ACKNOWLEDGEMENTS}

This research was financially supported by the National Taiwan University under Grant 95R0210 and by the National Science Council, Taiwan, under Grant NSC96-2221-E002-150-MY3.

\section{REFERENCES}

1. K. Zeng and K.N. Tu, Mater. Sci. Eng. R38, 55 (2002).

2. L.B. Liu, C. Andersson, J. Liu, and Y.C. Chan, Interpack 2003-35126, Int. Electronic Packaging Technical Conf. Exhib (New York: ASME, 2003), pp. 141-146.

3. L.B. Liu, C. Andersson, and J. Liu, J. Electron. Mater. 33, 935 (2004). doi:10.1007/s11664-004-0019-8.

4. C. Andersson, P. Sun, and J. Liu, J. Alloys Compd. 457, 97 (2008).

5. P. Sun, C. Andersson, X. Wei, Z. Cheng, D. Shangguan, and J. Liu, Mater. Sci. Eng. B 135, 134 (2006). doi:10.1016/ j.mseb.2006.08.051.

6. S.K. Kang and V. Ramachandran, Scripta Metall. 14, 421 (1980). doi:10.1016/0036-9748(80)90338-5.
7. K.Y. Lee and M. Li, Metall. Mater. Trans. 32A, 2666 (2001). doi:10.1007/s11661-001-0058-1.

8. M.Y. Chiu, S.Y. Chang, Y.H. Tseng, Y.C. Chan, and T.H. Chuang, Z. Metallkd. 93, 248 (2002).

9. T.H. Chuang, S.Y. Chang, L.C. Tsao, W.P. Weng, and H.M. Wu, J. Electron. Mater. 32, 195 (2003). doi:10.1007/s11664003-0193-0.

10. J.H. Lau, C.P. Wong, N.C. Lee, and R.S.W. Lee, Electronics Manufacturing: With Lead-Free, Halogen-Free, Conductive Adhesive Materials (New York: McGraw-Hill Handbooks, 2003).

11. T.H. Chuang, S.F. Yen, and M.D. Cheng, J. Electron. Mater. 35, 302 (2006). doi:10.1007/BF02692450.

12. T.H. Chuang, S.F. Yen, and H.M. Wu, J. Electron. Mater. 35, 310 (2006). doi:10.1007/BF02692451.

13. K. Ishida and T. Nishizawa, J. Phase Equil. 12, 88 (1991).

14. H. Okamato, J. Phase Equil. 14, 3 (1993).

15. U. Gosele and K.N. Tu, J. Appl. Phys 53, 3252 (1982). doi:10.1063/1.331028.

16. I.E. Anderson, J.C. Foley, B.A. Cook, J. Harringa, R.L. Terpstra, and O. Unal, J. Electron. Mater. 30, 1050 (2001). doi:10.1007/s11664-001-0129-5. 